International Journal of Current Microbiology and Applied Sciences

ISSN: 2319-7706 Volume 10 Number 10 (2021)

Journal homepage: http://www.ijcmas.com

\title{
Impact of Plant Growth Regulators on Sesame (Sesamum indicum L.) Yield and its Attributes
}

\author{
D. M. Hadiya ${ }^{1^{*}}$, H. S. Bhadauria ${ }^{1}$, K. P. Prajapati ${ }^{2}$, A. K. Singh ${ }^{3}$ and V. H. Kanabi ${ }^{4}$ \\ ${ }^{I}$ Department of Genetics and Plant Breeding, C. P. College of Agriculture, \\ ${ }^{2}$ Castor and Mustard Research Station, ${ }^{3}$ Bioscience Research Centre, \\ ${ }^{4}$ Department of Basic Science and Humanities, S. D. Agricultural University, \\ Sharadarkrushinagar-385 506, Gujarat, India \\ *Corresponding author
}

Keywords

Sesame, GA3,

NAA, CCC, SA,

Yield, Capsule,

Seed, Sesame

Article Info

Accepted:

05 September 2021

Available Online:

10 October 2021

\section{A B S T R A C T}

The experiment was conducted at Agronomy Instructional Farm, S. D. Agricultural University, Sardarkrushinagar during Kharif 2020 to examined the effect of different foliar spray of plant growth regulators viz., $\mathrm{GA}_{3}(100$ and $200 \mathrm{ppm}$ ), NAA (50 and $100 \mathrm{ppm}$ ), CCC (500 and $1000 \mathrm{ppm}$ ) and SA (500 and $1000 \mathrm{ppm}$ ) on seed yield and its related attributes of sesame variety (Gujarat Til 3). The research was laid out in randomized block design, with ten treatments in three replication under rainfed condition. $\mathrm{GA}_{3} 200$ ppm significantly increased seed yield and its attributes of sesame the number of capsule per plant, number of seeds per capsule, biological yield, harvest index and oil content.

\section{Introduction}

Sesame (Sesamum indicum L.) is an ancient oil yielding crop and popularly known as "Queen of Oilseeds". Sesame belongs to family pedaliaceae (Nayar, 1984). The genus Sesamum has 37 species, out of which Sesamum indicum L. is the dominant cultivated species, grown widely in tropical and subtropical areas for its edible uses viz. oil, proteins, vitamins, and amino acids etc. It originated from Africa and most its species distributed in Africa, India and the Far East Asia (Kobayashi et al., 1991).

Sesame is typically an erect branched annual $0.5-2 \mathrm{~m}$ in height with a well-developed root system. It is multi-flowered, and its fruit is a capsule containing a number of small oleaginous seeds.

Sesame seeds are very small in size and around four millimetre long two millimetre wide and one millimetre thick. They are pearl 
shaped, ovate, small, slightly flattened and somewhat thinner at the eye of the seed (hilum). The varieties and strains differ considerably in size, form, growth, flower colour, seed size, seed colour and composition. Plant hormones are organic substance produced naturally by plant to regulate their growth and development at very low concentration.

It is produced by plant itself but production of plant growth hormones is affected by different biotic and abiotic factor, which cause constraint in growth and development of plant. So, approaches of application of synthetic plant growth regulators to meat out the demand of plant hormones in crops observed good results.

Recently plant growth regulators are considered as new generation of agrochemicals which are not only known to modify plant architecture, but also enhance source-sink relationship as well as stimulate the translocation of photo-assimilates. Which help in better retention of flowers, pod and seed development.

\section{Materials and Methods}

A field experiment was carried out at Agronomy Instructional Farm, S. D. Agricultural University, Sardarkrushinagar during Kharif 2020. Geographically, Sardarkrushinagar is situated at $24^{\circ} 19^{\prime}$ North latitude and $72^{\circ} 19^{\prime}$ East longitudes with an elevation of 154.52 meter above the mean sea level and situated in the North Gujarat.

Climate of this region is sub-tropical type and comes under semi-arid region, in general, the monsoon is warm and moderately humid, winter is cold and dry, while summer is hot and dry. Maximum mean temperature ranged between 30.2 to $38.5^{\circ} \mathrm{C}$, while mean minimum temperature ranged between 15.8 to $27.4^{\circ} \mathrm{C}$ during the period of experimentation in Kharif 2020. The mean relative humidity recorded at morning and evening 61 to 90 and 37 to 93 per cent, respectively. Seeds of GT-3 variety of sesame (Sesamum indicum L.) obtained from the Castor-Mustard Research Station, S.D.A.U., Sardarkrushinagar and plant growth regulators (PGRs) purchased from open market.

Land selected for the experiment was sandy loam soil which brought to fine for sowing by applied two to three ploughing. The fertilizer @ $50 \mathrm{~kg} \mathrm{~N}$ and $25 \mathrm{~kg} \mathrm{P}_{2} \mathrm{O}_{5} /$ ha were applied as a basal dose at the time of sowing. The operations like gap filling, thinning, weeding, hoeing and plant protection measures were carried out regularly to ensure satisfactory crop growth.

A set of ten treatments of experiment was evaluated by using randomized block design (RBD) with three replication. Each treatments sown in four rows of 3.00 meter length with spacing $45 \mathrm{~cm}$ between row to row and $15 \mathrm{~cm}$ between plant to plant.

The experiment comprised of total 10 treatments viz. Control, Water spray, $\mathrm{GA}_{3} 100$ ppm, $\mathrm{GA}_{3} 200$ ppm, NAA 50 ppm, NAA 100 ppm, CCC 500 ppm, CCC 1000 ppm, SA 500 ppm and SA 1000 ppm foliar application at 30 and 50 days after sowing, evaluated by using randomized block design (RBD) with three replication.

\section{Observations}

Yield and yield related attributes i.e. number of capsule per plant, number of seed per capsule, number of chaffy seed per capsule, number of healthy seed per capsule, 1000 seed weight, seed yield per plant, seed yield per hectare, biological yield per plant, biological yield per hectare, harvest index and oil content. 


\section{Results and Discussion}

\section{Yield and yield attributes}

\section{Number of capsule per plant}

Evaluated the table 1 revealed that highest value of capsules per plant recorded with $\mathrm{GA}_{3}$ $200 \mathrm{ppm}$ followed by NAA $50 \mathrm{ppm}$ as compared to rest of all other treatments whereas other than these treatments rest of all treatments showed non-significant difference to each other, these results conceded with the finding of Sarkar et al., (2002) in soybean and Behera et al., (2017) in sesame.

\section{Number of seed per capsule}

Data indicated that the maximum numbers of seed per capsule were recorded with foliar application of $\mathrm{GA}_{3} 200 \mathrm{ppm}$ followed by $\mathrm{GA}_{3}$ 100 ppm, NAA 50 ppm, NAA 100 ppm, CCC $500 \mathrm{ppm}$ and SA $1000 \mathrm{ppm}$, over to rest of other treatments. However remaining treatments were found at par with each other.

These results were evident by the finding of Sarkar et al., (2002) in soybean, Akter et al., (2007) in mustard, Kalyankar et al., (2008) in soybean and Behera et al., (2017) in sesame.

\section{Number of chaffy seed per capsule}

Carefully perusal of data showed that minimum number of chaffy seeds per capsule recorded with NAA $50 \mathrm{ppm}$ followed by $\mathrm{GA}_{3}$ $200 \mathrm{ppm}$ as compared to rest of all other treatments, whereas maximum number of chaffy seed per capsule recorded with control.

More numbers of chaffy seeds per capsules showed in control and water spray as compared to other treatments it might be due to variation in translocation of assimilates toward seed, similar results were also obtained by Behera et al., (2017) in sesame.

\section{Number of healthy seed per capsule}

Data belongs to healthy seeds per capsule indicated that maximum number of healthy seeds per capsule were recorded with foliar application of $\mathrm{GA}_{3} 200 \mathrm{ppm}$ followed by NAA 50 ppm, NAA 100 ppm, SA 1000 ppm, CCC 1000 ppm, $\mathrm{GA}_{3} 100$ ppm and SA 500 ppm over to control and foliar spray of water.

Higher number of healthy seed per capsule produced by $\mathrm{GA}_{3} 200 \mathrm{ppm}$ because after anthesis $\mathrm{GA}_{3}$ can enhance the stigma vigor and correspondingly improved seed vigor. The results were concur with the finding of Kalyankar et al., (2008) in soybean, Behera et al., (2017) in sesame and Wang et al., (2019) in rice.

\section{0 seed weight $(\mathrm{g})$}

Examine the data of 1000 seed weight showed that highest value observed with foliar spray of CCC $500 \mathrm{ppm}$ followed by CCC $1000 \mathrm{ppm}$ over to rest of all other treatments. However minimum value of 1000 seed weight recorded with control, which was at par with remaining all treatments except SA 1000 ppm.

It is also concluded that increase in 1000 seed weight by CCC might be due to accelerated translocation of photo assimilate toward seed. Similar results were also obtained by Sontakey et al., (1991) in sesame, Sarkar et al., (2006) in sesame and Secondo and Reddy (2018) in sunflower.

\section{Seed yield}

Seed yield data indicated that the maximum seed yield recorded with foliar application of $\mathrm{GA}_{3}$ 200ppm followed by NAA $50 \mathrm{ppm}$ as compared to all other treatments. Whereas other treatments were observed at par with each other except NAA 100 ppm and $\mathrm{GA}_{3} 100$ ppm. 
Table.1 Effect of PGR on number of capsule per plant, number of seed per capsule, number of chaffy seed per capsule and 1000 seed weight, seed yield, biological yield, harvest index and oil content of sesame

\begin{tabular}{|c|c|c|c|c|c|c|c|c|c|}
\hline Treatments & $\begin{array}{c}\text { No. of } \\
\text { capsule } \\
\text { per plant }\end{array}$ & $\begin{array}{c}\text { No. of } \\
\text { seed per } \\
\text { capsule }\end{array}$ & $\begin{array}{c}\text { No. of } \\
\text { chaffy } \\
\text { seed per } \\
\text { capsule }\end{array}$ & $\begin{array}{c}\text { No. of } \\
\text { healthy } \\
\text { seed per } \\
\text { capsule }\end{array}$ & $\begin{array}{l}1000 \text { seed } \\
\text { weight } \\
\text { (g) }\end{array}$ & $\begin{array}{l}\text { Yield per } \\
\text { Hectare } \\
\quad(k g)\end{array}$ & $\begin{array}{l}\text { Biological } \\
\text { Yield per } \\
\text { Hectare } \\
(\mathrm{kg})\end{array}$ & $\begin{array}{c}\text { Harvest } \\
\text { index } \\
(\%)\end{array}$ & $\begin{array}{c}\text { Oil } \\
\text { Content } \\
(\%)\end{array}$ \\
\hline Control & 30.02 & 38.90 & 8.01 & 30.59 & 2.91 & 568.37 & 2185.5 & 25.48 & 46.09 \\
\hline Water & 30.70 & 39.78 & 7.55 & 32.56 & 2.95 & 575.61 & 2199.0 & 25.86 & 46.23 \\
\hline $\mathrm{GA}_{3}$ 100ppm & 32.43 & 43.47 & 6.63 & 36.55 & 3.11 & 650.24 & 2455.1 & 26.73 & 49.58 \\
\hline $\mathrm{GA}_{3}$ 200ppm & 36.97 & 44.99 & 4.44 & 40.31 & 3.14 & 740.03 & 2636.0 & 28.35 & 49.64 \\
\hline NAA 50ppm & 34.05 & 44.01 & 4.35 & 39.38 & 3.09 & 682.72 & 2548.7 & 27.11 & 48.21 \\
\hline NAA 100ppm & 32.73 & 43.68 & 5.49 & 38.64 & 3.10 & 666.60 & 2503.1 & 26.63 & 48.19 \\
\hline CCC 500ppm & 32.23 & 43.43 & 5.35 & 38.56 & 3.69 & 628.32 & 2369.0 & 26.67 & 48.62 \\
\hline CCC 1000ppm & 30.93 & 42.71 & 6.40 & 36.71 & 3.42 & 598.74 & 2266.7 & 26.31 & 48.46 \\
\hline SA 500ppm & 30.81 & 41.30 & 6.23 & 36.35 & 3.16 & 587.65 & 2225.6 & 26.25 & 47.10 \\
\hline SA 1000ppm & 31.79 & 43.20 & 5.86 & 37.46 & 3.20 & 611.23 & 2304.4 & 26.47 & 47.51 \\
\hline Mean & 32.26 & 42.54 & 6.03 & 36.71 & 3.18 & 630.95 & 2369.3 & 26.58 & 47.96 \\
\hline SEm \pm & 1.22 & 1.24 & 0.30 & 1.73 & 0.09 & 24.31 & 97.26 & 0.79 & 0.79 \\
\hline C.D at $5 \%$ & 3.63 & 3.68 & 0.90 & 5.14 & 0.28 & 72.22 & 288.98 & 2.34 & 2.34 \\
\hline C.V \% & 6.57 & 5.04 & 8.71 & 8.16 & 5.04 & 6.67 & 7.11 & 5.08 & 2.84 \\
\hline
\end{tabular}


Increased in seed yield can be attributed to the increased characters like plant height, number of branch, number of capsule per plant, number of healthy seed per capsule, number of leaves, leaf area, chlorophyll content and dry matter production, and partitioning of assimilaters toward seeds.

Present studies were also supported by Sarkar et al., (2002) in soybean, Akter et al., (2007) in mustard, Kalyankar et al., (2008) in soybean and Behera et al., (2017) in sesame.

\section{Biological yield}

Examine of the data showed that the higher value of biological yield obtained with foliar application of $\mathrm{GA}_{3} 200$ ppm followed by NAA 50 ppm, NAA 100 ppm, GA 100 ppm and CCC $500 \mathrm{ppm}$ as compared to rest of all treatments.

Foliar spray of $\mathrm{GA}_{3} 200 \mathrm{ppm}$ is increased plant dry matter which directly associated to increased biological yield. Similar results were obtained by Sontakey et al., (1991) in sesame, Sarkar et al., (2002) in soybean and Behera et al., (2017) in sesame.

\section{Harvest index}

Data related to harvest index indicated that the superior value of harvest index recorded with $\mathrm{GA}_{3} 200 \mathrm{ppm}$ followed by NAA $50 \mathrm{ppm}, \mathrm{GA}_{3}$ 100 ppm, CCC 500 ppm, NAA 100 ppm, SA 1000 ppm, CCC 1000 ppm and SA 500 ppm over to control and water spray.

Harvest index is ratio of economic yield to biological yield so foliar application of $\mathrm{GA}_{3}$ $200 \mathrm{ppm}$ recorded highest value of seed yield due to that increase the value of harvest index.

Similar results were also reported by Sontakey et al., (1991) in sesame and Vekaria et al., (2017) in sesame.

\section{Oil content in per cent $(\%)$}

Data related to oil content indicated that the higher per cent of oil content registered with foliar application of $\mathrm{GA}_{3}$ 200ppm followed by $\mathrm{GA}_{3} 100$ ppm, CCC 500 ppm, CCC 1000 ppm, NAA 50 ppm, NAA 100 ppm and SA 1000 ppm over to control, water spray and SA 500 ppm our results were evident by the finding of Sontakey et al., (1991) in sesame, Vekaria et al., Khan and Khan (2016) in soybean and Thuc et al., (2021) in sesame.

Among all the characters studied related to seed yield production and their distribution in component parts of plant and it was observed that the $\mathrm{GA}_{3} 200 \mathrm{ppm}$ treatment was found superior followed by NAA 50 ppm under rainfed conditions. Therefore on the basis of these observations, foliar application of $\mathrm{GA}_{3}$ 200 ppm was most promising treatment due to highest seed yield under rainfed condition.

\section{References}

Akter, A.; Ali, E.; Islam, M. M. Z.; Karim, R. and Razzaque, A. H. M. (2007).Effect of $\mathrm{GA}_{3}$ on growth and yield of mustard. International Journal Sustainable Crop Production,2(2):1620.

Behera, S.; Padhiary, A. K.; Nanda, P. K.; Rout, S.; Nayak, A. and Behera, D. (2017).Influence of plant growth regulators on chlorophyll content of different sesame (Sesamum indicum L.).

Kalyankar, S. V.; Kadam, G. R.; Borgaonkar, S. B.; Deshmukh, D. D. and Kadam, B. P. (2008). Effect of foliar application of growth regulators on seed yield and yield component of soybean (Glycine max L.) Asian Journal Biological Science.3(1): 229-230.

Khan, R. and Khan, N. (2016).Effect of plant growth regulators on physio-logical 
and biochemical parameters in soybean (Glycine max L.). M.Sc. (Ag.) Thesis, Vasantrao Naik Marathwada Krishi Vidyapeeth, Parbhani.103.

Kobayashi, T. (1991). Cytogenetics of sesame (Sesamum indicum L.). International chromosome engineering plants Genetic Breeding Evolution (Eds.), Netherlands: 581-592.

Nayar, N. M. and Simmonds, N. W. (1984). Evolution of crop plants in sesame. Longman, London:231-233.

Sarkar, P. K.; Haque, M. S. and Karim, M. A. (2002). Effects of GA and IAA and their frequency of application on morphology, yield contributing characters and yield of soybean. Pakistan Journal of Agronomy.1(4): 119-122.

Secondo, E. S. P. and Reddy, Y. A. N. (2018). Plant growth regulators improve sink strength and yield of sunflower. International Journal Microbiology and Applied Science, 7(10): 111-119.

Sontakey, P. Y.; Belsore, W. Y.; Deotale, R.
D. and Wankhede, S. Z. (1991). Relative influence of growth hormones on growth and yield performance of sesamum. New agric., 1(2): 208-208.

Thuc, L. V.; Sakagami, J. I.; Khuong, N. Q.; Orgill, S.; Huu, T. N.; Lang, N. T. and Nhan, P. P. (2021). Effects of Spraying Gibberellic Acid Doses on Growth, Yield and Oil Content in Black Sesame (Sesamum indicum L.) Asian Journal Crop Sciences. 13 (1): 1-8.

Vekariya, G. B.; Rakholiya, K. D.;Vora, V. D.; Patel, J. T., Sutariya, G. S. and Vekariya, P. D. (2017). Response of sesame (Sesamum indicum L.) to growth regulators under dry farming condition. International Journal Microbiology and Applied Science.6(3): 1113-1120.

Wang, X.; Zheng, H.; Tang, Q.; Mo, W. and Ma, J. (2019). Effects of gibberellic acid application after anthesis on seed vigor of indica hybrid rice (Oryza sativa L.). Agronomy.9(2): 861.

\section{How to cite this article:}

Hadiya, D. M., H. S. Bhadauria, K. P. Prajapati, A. K. Singh and Kanabi, V. H. 2021. Impact of Plant Growth Regulators on Sesame (Sesamum indicum L.) Yield and its Attributes. Int.J.Curr.Microbiol.App.Sci. 10(10): 102-107. doi: https://doi.org/10.20546/ijcmas.2021.1010.013 